\title{
Pembuatan Karya Seni Menggambar Dekoratif pada Caping dalam Mata Pelajaran SBK Siswa SD Kota Bengkulu
}

\author{
Helce Marisa Putri \\ Universitas Bengkulu \\ helcemarisa@gmail.com \\ Hasnawati \\ Universitas Bengkulu \\ hasnaapril21@gmail.com \\ Nani Yuliantini \\ Universitas Bengkulu \\ nani.yuliantini97@gmail.com
}

\begin{abstract}
This study aims to describe the process of making and drawing decorative work of caping in the subjects of Art Culture and Skills (SBK) class III A SD Negeri 07 Kota Bengkulu. The type and method of this research is skin research and descriptive method with participant observation technique. The research subjects were all students of class III A SD Negeri 07 Kota Bengkulu which amounted to 31 people. The research instrument is a human instrument, using obsevation guidelines, interview guides, and guidelines of the work. Data collection techniques such as observation, interview, and documentation / work. The data analysis of the process of making works is done by studying the data and then reducing, display, and drawing conclusions. Analysis of the work data will be discussed by looking at the elements and principles of art that exist. The process of making six works of decorative drawing art on the caping begins with a discussion determines the motive to be chosen in making the work. Followed by preparing tools and materials. After that give the basic paint on the caping. Selanjunya make motif design and thicken motifs and then coloring motifs. Six pieces of artwork drawing decorative on the caps made students contain elements and principles of fine art that contains elements of lines, fields, and colors. Placement of these motives on the caping contains the principles of art that is the principle of unity, balance, rhythm, emphasis and harmony.
\end{abstract}

Keywords: SBK Learning, Fine Arts, Decorative Caping Work.
Abstrak
Penelitian ini bertujuan untuk mendeskripsikan proses pembuatan dan menggambar karya dekoratif caping pada mata pelajaran Seni Budaya dan Keterampilan (SBK) kelas III A SD Negeri 07 Kota Bengkulu. Jenis dan metode penelitian ini adalah penelitian kulit dan 
metode deskriptif dengan teknik observasi partisipan. Subjek penelitian adalah semua siswa kelas III A SD Negeri 07 Kota Bengkulu yang berjumlah 31 orang. Instrumen penelitian adalah instrumen manusia, menggunakan pedoman observasi, panduan wawancara, dan pedoman pekerjaan. Teknik pengumpulan data seperti observasi, wawancara, dan dokumentasi / pekerjaan. Analisis data dari proses pembuatan karya dilakukan dengan mempelajari data dan kemudian mengurangi, menampilkan, dan menggambar kesimpulan. Analisis data pekerjaan akan dibahas dengan melihat unsur dan prinsip seni yang ada. Proses pembuatan enam karya seni lukis dekoratif pada caping dimulai dengan diskusi menentukan motif yang akan dipilih dalam pembuatan karya. Dilanjutkan dengan menyiapkan alat dan bahan. Setelah itu beri cat dasar pada caping. Selanjunya membuat desain motif dan mengentalkan motif kemudian mewarnai motif. Enam buah karya seni yang digambar dekoratif pada tutupnya membuat siswa mengandung unsur dan prinsip seni rupa yang mengandung unsur garis, bidang, dan warna. Penempatan motif-motif ini pada caping berisi prinsip-prinsip seni yaitu prinsip persatuan, keseimbangan, ritme, penekanan dan harmoni.

Kata kunci: Pembelajaran SBK, Seni Rupa, Karya Dekoratif Caping.

\section{Pendahuluan}

Seni Budaya dan Keterampilan (SBK) merupakan salah satu mata pelajaran yang diajarkan di sekolah dasar. Pendidikan SBK sebagai mata pelajaran di sekolah penting keberadaannya, karena pendidikan ini memiliki sifat multilingual, multidimensional, dan multikultural (Susanto, 2013:262). Pendidikan SBK pada dasarnya merupakan pendidikan seni yang berbasis budaya yang aspeknya meliputi seni rupa, seni musik, seni tari dan seni keterampilan. Pendidikan seni dapat membantu para siswa untuk mengembangkan kemampuanya baik bersifat intelektual, emosional, maupun fisik dan kreatif.

Pendidikan SBK bisa membuat anak menjadi lebih kreatif. Sesuai dengan pendapat Sumanto (2011: 27) bahwa pendidikan SBK dapat memancing timbulnya kemampuan kreatif. Selain itu Susanto (2013: 261) juga menyatakan bahwa pendidikan SBK di sekolah memiliki fungsi dan tujuan untuk mengembangkan kemampuan dalam berkarya dan berkreasi. Oleh karena itu pembelajaran SBK menjadi salah satu sarana penting untuk mengembangkan keretavitas siswa dalam berkarya dan berkreasi seni.

Mata pelajaran SBK terdapat beberapa aspek yaitu seni rupa, seni tari, seni musik, dan keterampilan. Menurut Susanto (2013: 263) pada jenjang SD secara spesifik mata pelajaran SBK meliputi aspek-aspek: seni rupa, seni musik, seni tari, seni drama, dan keterampilan. Pada penelitian ini peneliti memilih seni rupa, seni rupa sendiri merupakan cabang seni yang diciptakan dengan menggunakan unsur rupa dan dapat diapresiasi melalui indera mata. Unsur rupa tersebut meliputi titik, garis, bentuk, bangun, warna, tekstrur, dan gelap terang. Siswa dituntut untuk mengetahui dan memahami unsur-unsur tersebut sehingga lebih memudahkannya untuk mengembangkan kreativitas, serta dapat memahami dasar dalam pembuatan karya seni rupa. Hal ini sesuai pendapat Kamaril (2006: 1.25-1.29) yang menjelaskan bahwa siswa dapat mengekspresikan atau menuangkan ide pikiran maupun perasaannya kedalam bentuk karya yang menjadi cerminan keterampilan dan kreativitas yang dimilikinya. 
Pada saat ini pembelajaran Seni Budaya dan Keterampilan (SBK) dalam penerapannya belum sesuai dengan tujuan kurikulum. Berdasarkan Permendiknas No.22 Tahun 2006 yaitu peserta didik harus memiliki kemampuan menampilkan kreativitas melalui seni budaya dan keterampilan. Berdasarkan pengamatan awal peneliti yang telah dilakukan pada tanggal 20 Januari 2018 di SD Negeri 07 Kota Bengkulu, masih banyak guru dalam proses pembelajaran seni khususnya dalam pembelajaran Seni Rupa hanya mengajarkan menggambar bebas. Hal ini berdampak pada pendidikan seni yang membuat siswa tidak termotivasi, kreativitas menjadi terhambat dan terbatas. Oleh karena itu perlu dilakukan upaya untuk melatih dan mengembangkannya melalui pendidikan seni. Banyak kegiatan yang bisa dilakukan, misalnya menggambar bentuk, menggambar illustrasi, menggambar huruf hias dan menggambar dekoratif. Pada penelitian ini peneliti memilih menggambar dekoratif sebagai pendidikan seni yang dapat meningkatkan kreativitas, menarik serta memuat unsur seni rupa.

Menggambar dekoratif adalah kegiatan menghias benda. Menurut Sumanto (2011: 90) bahwa menggambar dekoratif adalah kegiatan membuat gambar yang berbentuk hiasan bidang atau menghias benda. Selain itu menurut Kamaril, dkk (2006: 4.22) menggambar dekoratif yakni corak atau motif hiasan yang menutupi benda untuk memperindah benda tersebut. Benda yang digunakan untuk menggambar dekoratif pada penelitian ini adalah benda tiga dimensi yaitu caping.

Caping biasa digunakan oleh para petani ketika sedang berkerja di sawah, namun caping juga bisa digunakan untuk hiasan. Oleh karena itu, peneliti memilih caping sebagai objek hias karena selain mudah didapat, caping juga aman bagi anak sekolah dasar. Caping termasuk benda tiga dimensi karena yang dimaksud benda tiga dimensi adalah benda yang dapat dilihat lebih dari satu arah. Menurut Nana Sudjana (2011: 101) benda tiga dimensi adalah suatu alat peraga yang mempunyai panjang, lebar, serta tinggi dan dapat diamati dari sudut pandang mana saja. Menghias caping ini bertujuan untuk membuat atau mendekor caping menjadi benda hias yang lebih indah dan menarik, melalui kegiatan pembelajaran SBK tentang menggambar dekoratif.

Menggambar dekoratif pada caping menjadi suatu kegiatan yang banyak manfaat khususnya untuk siswa usia sekolah dasar yaitu mengembangkan kreativitas. Menurut Tabrani (2014) menggambar dekoratif juga bermanfaat untuk menstimulasi daya imajinasi peserta didik. Karena kegiatan ini memberikan kesempatan kepada peserta didik untuk menggambar berdasarkan imajinasi mereka sendiri. Selain untuk menggembangkan kreativitas anak, kegiatan ini juga menciptakan gerakan yang dilakukan oleh anak secara sadar yang dipengaruhi oleh stimulus dari lingkungannya (informasi verbal atau lisan, gambar, dan alat lainnya) yang dapat direspon oleh anak.

Materi menggambar dekoratif juga dimuat dalam mata pelajaran Seni Budaya dan Keterampilan (SBK) pada Kurikulum Tingkat Satuan Pendidikan (KTSP). Yaitu terdapat pada standar kompetesi (SK) dan kompetensi dasar (KD) pada kelas III semester dua yakni SK 9 Mengekspresikan diri melalui karya seni rupa, dan KD 9.2 Memberi warna pada benda tiga dimensi. Jadi pembelajaran dekoratif pada caping baik dipelajari oleh siswa, karena selain manfaatnya, materi tentang dekoratif juga terdapat pada Kurikulum Tingkat Satuan Pendidikan.

Berdasarkan latar belakang di atas, maka rumusan masalah dalam penelitian ini adalah "Bagaimana proses pembuatan karya seni menggambar dekoratif pada caping dan hasil karya seni menggambar dekoratif pada caping dalam pembelajaran SBK kelas III A SD 07 Kota Bengkulu?" 
Adapun tujuan penelitian ini adalah untuk mendeskripsikan proses pembuatan karya seni menggambar dekoratif pada caping dan hasil karya seni menggambar dekoratif pada caping pada pembelajaran SBK kelas III A SD 07 Kota Bengkulu.

\section{Metode}

Penelitian ini menggunakan jenis penelitian kualitatif dengan metode deskriptif dan dilakukan dengan observasi berperanserta/participant observation oleh peneliti. Sugiyono (2010: 204) menyebutkan bahwa "dengan observasi partisipan ini, maka data yang diperoleh akan lebih lengkap, tajam, dan sampai mengetahui pada tingkat makna dari setiap perilaku yang nampak". Peneliti terlibat langsung di dalam kegiatan yang dilakukan yaitu sebagai guru dan melakukan pengamatan dan wawancara terhadap proses pembuatan karya seni menggambar dekoratif pada caping dan hasil karya seni menggambar dekoratif pada caping pada mata pelajaran SBK di kelas III A SD Negeri 07 Kota Bengkulu.

Subyek dalam penelitian ini adalah seluruh siswa kelas III A yang berjumlah 31 siswa. Penelitian ini dilaksanakan di SD Negeri 07 Kota Bengkulu pada mata pelajaran Seni Budaya dan Keterampilan (SBK) yang beralamat di Jln. Sentot Ali Basyah Kelurahan Bajak Kecamatan Teluk Segara Provinsi Bengkulu. Penelitian ini dilaksanakan pada semester dua tahun ajaran 2017/2018.

Instrumen penelitian adalah human instrument, dengan menggunakan instrumen pendukung yaitu pedoman observasi, pedoman wawancara dan pedoman hasil karya. Peneliti menggunakan pedoman observasi untuk melihat proses pembuatan karya macrame. Pedoman wawancara untuk mendapatkan pernyataan tentang proses pembuatan karya macrame tersebut. Peneliti menggunakan pedoman hasil karya berdasarkan unsur-unsur dan prinsip-prinsip seni rupa untuk melihat apakah unsur-unsur dan prinsip-prinsip terlihat atau tidak dalam karya.

Teknik pengumpulan data yang digunakan dalam penelitian ini berupa observasi, wawancara dan dokumentasi. Teknik observasi dan wawancara dilakukan untuk mendapatkan data tentang proses pembuatan karya. Dokumentasi digunakan sebagai pelengkap data, dokumentasi yang digunakan berupa foto hasil karya seni menggambar dekoratif pada botol yang telah dibuat siswa tahun sebelumnya dan hasil karya yang telah dibuat peneliti sebelum melakukan penelitian.

Analisis data yang dilakukan adalah analisis data kualitatif. Analisis data proses pembuatan karya dilakukan dengan mengumpulkan data, kemudian data dianalisis dengan menelaah hasil reduksi data, lalu data disajikan dalam bentuk uraian deskriptif dan ditarik kesimpulan. Analisis data hasil karya akan dibahas dengan melihat unsur-unsur dan prinsip-prinsip seni rupa yang ada.

\section{Hasil}

Adapun data proses pembuatan karya seni menggambar dekoratif pada caping yang diperoleh melalui observasi dan wawancara pada pembelajaran SBK, Setiap kelompok telah melakukan proses pembuatan yang terdiri dari beberapa tahapan yaitu pertama proses persiapan terdiri dari pengumpulan alat dan bahan. Kedua yaitu proses memberi cat dasar pada caping dan ketiga yaitu mendesain motif kemudian proses keempat yang merupakan proses terakhir yaitu pewarnaan. Proses pembuatan karya seni menggambar dekoratif pada caping tersebut akan dijabarkan satu-persatu. 
Tahap pertama yang dilakukan setiap kelompok adalah persiapan. Persiapan ini yaitu pengumpulan alat dan bahan dalam penelitian ini telah disediakan peneliti berupa kaus (persegi dan pensi), caping dan pewarna ada 12 warna. Alat yang lain dipersiapan oleh siswa seperti pensil dan sepidol berserta pelengkapan tulis yang lainya. Perwakilan setiap kelompok diminta maju kedepan kelas mengambil alat dan bahan tersebut. Dalam pengumpulan alat dan bahan mereka terlihat tidak kesulitan, mereka dengan mudah dan cepat mengumpulkannya.

Tahap kedua yaitu proses memberi cat dasar pada caping. Untuk proses memberi cat dasar pada caping sebelumnya peneliti memberi arahan kesemua kelompok untuk memilih cat berwarna putih karena cat tersebut pada saat mendesain motif hias akan lebih tampak dibendingkan dengan warna cat yang lain pada proses ini sesuai dengan pendoman observasi. Sebelum kegiatan memberi cat dasar dimulai, setiap kelompok menyediakan kertas untuk alas caping. Caping diberi alas agar saat proses pemberian cat nanti tidak mengenai meja mereka. Setelah itu mereka melakukan pembagian tugas, ada yang memberi cat pada caping, ada yang memegang caping dan ada yang memegang cat yang akan digunakan. Pada kegiatan memberi cat dasar pada caping, siswa tidak merasa kesulitan untuk mewarnai caping. Namun, masih ada juga beberapa siswa dalam kelompok yang belum menujukkan keseriusan karena masih bermain-main.

Selanjutnya proses mendesain motif. Sebelum proses mendesain motif hias pada caping peneliti menjelaskan terlebih dahulu langkah-langkah apa saja yang akan mereka kerjakan. Pertama peneliti menjelaskan bahwa menggambar dekoratif ini terdapat empat motif yang sudah dijelaskan sebelumnya pada pertemuan pertama. Motif-motif tersebut yaitu motif geometris, tumbuhan, hewan, dan manusia. Dalam memilih motif siswa bebas memilih motif yang mereka mau boleh motifnya dicampur atau pun tidak sesuai ide dan daya kreativitasnya masing-masing. Sebelum memilih motif siswa terlebih dahulu berdiskusi kepada teman kelompoknya untuk memilih motif apa yang akan digunakan untuk mendesain gambar dekoratif. Setelah motif sudah ditentukan selanjutnya proses mendesain motif dengan menggunakan alat yaitu pensil. Dalam proses ini banyak siswa yang mengalami kesulitan karena mereka belum pernah menggambar di permukaan yang tidak rata, namun dengan melihat peneliti mencontohkan cara menggambar di permukaan caping siswa menjadi paham dan bersemangat untuk menyelesaikan gambaran mereka. Setelah motif didesain selanjutnya mempertebal garis-garis motif dengan menggunakan spidol setiap kelompoknya melakukan dengan hati-hati supaya hasil motif yang mereka buat tampak jelas dan mempermudah untuk mewarnai motif.

Langkah terakhir yang dilakukan yaitu proses pewarnaan. Dalam proses pewarnaan secara berkelompok, siswa membagi tugas antara kelompoknya ada yang memberi warana ada memegang pewarna dan ada yang memegang caping. siswa melakukannya dengan semangat, bekerja sama dan sangat antusias serta saling menghargai atas hasil pewarnaan telah dibuat oleh teman sekelompoknya. Namun ada juga beberapa siswa yang masih bermain-main saat proses pembuatan karya yang mengakibatkan kurangnya ketelitian sehingga masih ada yang karyanya belum rapi dan banyak belepotan. Kendala dalam peroses pewarnaan ini yaitu dalam memilih warna yang cocok untuk motif yang mereka buat yang dimana masih banyak yang belum berani menggunakan 12 macam warna yang beragam. Setelah dilihat hasil karya yang mereka buat kebanyakan siswa cuman menggunakan 6 warna di setiap kelompoknya. Dan siswa cendrung memilih warna yang cerah dibandingkan menggunakan warna yang gelap.

Karya yang telah dibuat oleh masing-masing kelompok berjumlah 6 buah karya. Karya dari masing-masing kelompok dilihat dan dideskripsikan berdasarkan unsurunsur dan prinsip-prinsip seni rupa. Unsur-unsur seni rupa yaitu garis, bidang, dan 
warna. Prinsip-prinsip seni rupa yaitu kesatuan, keseimbangan, irama, penekanan dan keselarasan/keseimbangan.

Pada setiap karya terdapat banyak garis. Garis yang didapat dari karya ini terbentuk dari beberapa motif. Pada karya kelompok 1 terdapat garis zig-zag dan bergelombang. Karya kelompok 2 terdapat garis tegak, mendatar, lengkung dan bergelombang. Karya kelompok 3 terdapat garis lengkung dan zig-zag. Pada karya kelompok 4 terdapat garis mendatar, tegak, miring, lengkung, zig-zag dan bergelombang.. karya kelompok 5 terdapat garis lengkung, zig-zag, dan bergelombang. Pada karya kelompok 6 terdapat garis lengkung dan bergelombang.

Unsur bidang yang terdapat dalam karya adalah bidang yang terbentuk dari gabungan garis yang dihasilkan motif sehingga memiliki makna keindahan. Bidang yang terdapat pada karya kelompok 1 yaitu bidang non geometris. Karya kelompok 2 yaitu geometris. Karya kelompok 3 yaitu non geometris. Karya kelompok 4 yaitu geometris dan non geomteris. Karya keompok 5 yaitu non geomteris. Pada karya kelompok 6 yaitu non geometris.

Warna dalam karya ini terdapat pada warna motif dan latar yang digunakan. Pada karya kelompok 1 menggunakan warna merah, biru dan kuning yang termasuk kedalam warna primer serta warna hitam yang termasuk kedalam warna netral. Karya kelompok 2 menggunakan warna merah, kuning, biru warna primer, hitam dan putih warna netral, hijau dan orange warna sekunder dan coklat warna tersier. Karya kelompok 3 menggunakan warna kuning, merah, dan biru warna primer. Karya kelompok 4 menggunakan warna merah, kuning dan biru warna perimer, hijau warna sekunder, dan hitam warna netral. Karya kelompok 5 menggunakan warna putih (netral), warna merah, kuning, biru(perimer) dan orange ( sekunder). Karya kelompok 6 menggunakan warna primer (merah, kuning dan biru) dan warna nertal (hitam).

Selain memperhatikan unsur seni rupa seperti garis, bidang, warna dan gelap terang pembuatan karya seni menggambar dekoratif pada caping juga menggunakan aturan dalam menatanya hingga menjadi karya yang indah yaitu prinsip-prinsip seni rupa.

Prinsip yang pertama adalah prinsip kesatuan. Kesatuan dalam semua karya sudah telihat baik. Pada setiap karya kelompok telah menggabungkan beberapa motif, karya kelompok 1,3,4,dan5 itu kesatuanya sudah nampak dengan memilih 2 motif sementara karya kelompok 2 dan 6 itu hanya menggunakan 1 motif.

Prinsip keseimbangan yang terdapat dalam karya ini setiap karya perkelompok sudah menunjukan keseimbangan yang baik akan tetapi masi terdapat keseimbangan yang kurang di tunjukan pada karya kelompok 5 yang dimana motif digunakan terlalu banyak dan letaknya tidak berarturan.

Prinsip penekanan yang terdapat pada karya ini yaitu motif yang menjadi objek pada karya yang dibuat. Pada setiap karya kelompok telah menujukan penekaan masing-masing pada karya kelompok 1 menujukan bunga yang menjadi objeknya, karya kelompok 2 menujukan gambar bangunan yang menjadi objeknya karya kelompok 3 bunga raflesia dan bunga lain yang menjadi objeknya, karya kelompok 4 gambar bunga rafelesia dan rumah yang menajdi objeknya, karya kelompok 5 bunga yang menjadi objeknya, dan yang karya kelompok 6 ikan yang menjadi objek atau penekanannya.

Prinsip selanjutnya adalah prinsip irama. Irama dalam karya ini yaitu keteraturan mendesain motif yang digunakan. Jadi setiap karya yang dibuat menghasilkan irama dari pengulangan motif tersebut. Semua kelompok menggunakan irama 
repititif dan progresif yaitu pengulangan motif dengan ukuran yang sama dan pengulangan motif dengan ukuran yang berbeda. Irama progresif ini terdapat pada kelompok 1, 2, 3 dan 5 sementara irama repatitif terdapat pada keolpok 4 dan 6 .

Selanjutnya prinsip keselarasan atau keserasian, Secara keseluruhan karya yang dihasilkan setiap kelompok dalam pemilihan motif dan warna, sudah terlihat selaras dan serasi, namun ada beberapa karya kelompok yang perlu perbaikan. Seperti karya kelompok 6 yang kurang selaras dalam pemilihan warna karena warna terlihat kontras jika hitam digabungkan dengan putih dan merah . karya kelompok 4 yang membuat motif kontras antar motif rumah dan bunga rafles terlihat sama besar seharusnya ukuran bunga lebih kecil dari rumah. Dan karya kelompok 1 menggunakan warna yang tidak rapi sehingga terlihat kurang menarik.

\section{Pembahasan}

Proses yang dilakukan siswa untuk membuat karya seni menggambar dekoratif pada caping langkah pertama yang dilakukan adalah tahap penataan awal yang terdiri dari persiapan alat dan bahan yang dibutuhkan dalam pembuatan karya. Untuk persiapan ini peneliti sudah sebagian menyiapkan alat dan bahan untuk diberi dengan setiap kelompok, alat dan bahan yang peneliti siapakan berupa kuas (2 yang berukuran sedang berbentuku persegi dan 3 yang berukuran kecil 2 berbentuk persegi 1 berbentuk pensil), caping dan pewarna. Dan siswa menyiapkan pensil, spidol, kertas, koran dan alat tulis yang lainya. Pada persiapan alat ini, masing-masing kelompok telah melakukan persiapan yang cukup baik, namun ada dua kelompok yang masih belum melengkapi alat-alat yang dibutuhkan. Jika salah satu kelompok terdapat kekurangan dari segi persiapan alat, maka pengerjaan karya akan menjadi terhambat, karya yang dihasilkan kurang maksimal, selain itu akan mengganggu pekerjaan kelompok lain yang persiapannya jauh lebih baik dibandingkan kelompok yang kurang persiapannya. Namun, dari permasalahan tersebut masih bisa diatasi karena peneliti telah memberikan pinjaman alat bagi kelompok yang mengalami kekurangan alat.

Setelah persiapan pertama selesai maka masuk pada langkah yang kedua yaitu pelaksanaannya proses memberi cat dasar pada caping dengan menggunakan kuas. Warna dasar yang digunakan yaitu warna putih, karena dengan menggunakan warna putih akan lebih jelas untuk proses pembuatan motif atau mendesain motif dengan menggunakan pensil. Pemberian warna cat dasarnya ke seluruh permukaan caping sampai semua cat rata dan rapi, dalam prosesnya tidak terlalu sulit bagi siswa karena proses pengecatanya keseluruh caping dan tidak ada batasannya. Setelah proses memberi cat dasar pada caping selesai lanjut ke proses pengeringan.

Setelah caping mengering, langkah ketiga yaitu proses mendesian motif dengan menggunakan pensil, sebelum menggambar motif setiap kelompok berdiskusi telebih dahulu untuk memilih motif apa saja yang aka mereka pilih, disini peneliti memberi kebebasan kepada setiap kelompoknya untuk memilih motif sesuai imajinasi dan kreativitas mereka sendiri. Motif yang peneliti jelaskan ada empat macam yaitu motif tumbuhan, hewan, manusia dan geometris. Selanjutnya menggambar motif dipermukaan caping dengan menggunakan pensil, namun proses ini banyak siswa menggalami kesulitan karena mereka belum pernah menggambar di permukaan yang tidak rata namun disini peneliti memberi arahan dan memberi contoh bagaimana cara untuk menggambar motif di permukaan caping. Setelah mereka melihat dan mendegarkan penjelasan peneliti mereka mulai mengerti dan melanjutkan proses pemberian motifnya. Setelah motif yang mereka buat selesai selanjutnya motif yang mereka gambar dipertebal dengan menggunakan spidol, supaya motif yang mereka buat terlihat lebih jelas dan mempermudah disaat proses pemberian warna. 
Setelah proses menggambar motif selesai langkah terakhir yaitu pemberian warna pada motif dan latar pada permukaan caping. Proses pemberian warna ini menggunakan 3 kuas yang beukuran kecil 2 berbentuk pesegi 1 berbentuk pensil. Sebelum pemberian warna peneliti sudah menyiapkan 12 warna yang berbeda-beda siswa bebas memilih warna apa yang akan mereka gunakan sesuai dengan motif apa yang mereka buat, namun sebelum pemberian warna siswa terlebih dahulu berdiskusi bersama kelompoknya untuk memilih warna apa yang akan mereka gunakan. Disini terdapat kendala dimana kelompok 6 dan kelompok 2 masih bingung untuk memilih warna apa yang sesuai untuk motif yang mereka buat. Namun peneliti sedikit memberi arahan kepada kelompok yang menggalami kesulitan. Selanjutnya proses pemberian warna dalam proses pemberian warna masih banyak terdapat warna yang mereka gunakan belum telihat begitu rapi. Hal ini sesuai dengan Muliawan (2016: 1) bahwa kreativitas sangat terkait dengan kebebasan pribadi. Sikap menerima anak dengan segala kekurangan dan kelebihannya akan membuat anak lebih berani mencoba, berinisiatif dan berbuat sesuatu secara sepontan. Sikap ini sangat di perlukan dalam pengembangan kreativitas. Langkah pembuatan karya menggambar dekoratif pada caping yang dilakukan siswa telah sesuai dengan langkah dalam proses pembuatan karya menurut Sumanto (2011: 90-95) terdiri dari proses persiapan alat dan bahan, langkah kerja (memberi cat dasar pada caping, mendesain motif hias, memberi pewarna)

Secara keseluruhan, proses pembuatan karya seni menggambar dekoratif pada caping dilakukan dengan menyenangkan, tidak ada batasan siswa dalam mengembangkan kreativitasnya.

Dalam hasil masing-masing karya yang telah dibuat oleh siswa telah memuat unsurunsur dan prinsip seni rupa sehingga menjadi suatu karya yang indah. Adapun unsur-unsur yang dilihat dalam karya sesuai dengan pendapat yang telah dikemukakan oleh Kamaril,dkk (2006: 3.5-3.15), unsur-unsur dasar karya seni rupa antara lain titik, garis, bidang, warna, bentuk, tekstur, dan gelap terang. Sedangkan prinsip-prinsip seni rupa yang dilihat berdasarkan pendapat Kamaril (2006: 3.21 3.27) meliputi prinsip kesatuan, keseimbangan, irama, proporsi, penekanan dan keserasian.

Adapun unsur-unsur utama dalam karya seni menggambar dekoratif pada caping yakni adanya garis, bidang, warna dan gelap terang. Sedangakan prinsip utama dalam karya seni menggambar dekoratif pada caping yaitu prinsip kesatuan, keseimbangan, irama, penekanaan dan keserasian. Penggunaan unsur-unsur dan prinsip-prinsip ini tidak hanya membuat karya menjadi menarik namun juga memiliki banyak manfaat yang menjadikan karya ini cocok untuk dijadikan suatu materi rutin pada pembelajaran seni rupa di sekolah dasar.

Unsur seni rupa yang pertama adalah unsur garis. Garis merupakan perpanjangan dari susunan titik-titik yang memiliki panjang namun relatif tidak memiliki lebar. Adapun pendapat Kamaril (2006: 3.6) bahwa "dengan garis yang disambung dan digabungkan akan terwujud bentuk". Garis dapat dibedakan menjadi garis lurus, lengkung, spiral dan putus-putus. Pada karya siswa sudah menerapkan prinsip garis. Garis yang dimaksud adalah garis yang telah ada pada motif yang mereka buat. Garis yang terlihat pada karya setiap kelompoknya berupa garis lurus, garis lengkung dan bergelombang namun pada setiap kelompok karya yang mereka buat lebih dominan dengan menggunakan garis lengkung dan hampir semuanya terlihat dimasing-masing karya.

Unsur kedua yaitu bidang. Bidang merupakan sebuah area sebagai wujud pengembangan garis yang memiliki panjang dan lebar. Hal ini sesuai dengan 
pendapat Kamaril (2006: 3.7) bahwa "bidang merupakan pengembangan garis-garis yang melingkupi dari beberapa sisi". Bidang yang digunakan oleh semua karya ini berupa bidang geometris seperti persegi panjang, segi tiga, persegi dan no geometris seperti tumbunhan, hewan dan manusia. Disetiap kelompoknya banyak menggunakan bidang non geometris karena bidang ini memiliki motif tumbuhan hewan dan manusia.

Unsur ketiga yaitu unsur warna. Warna pada karya seni menggambar dekoratif pada caping cukup penting. Dengan pemilihan warna yang tepat dapat membuat karya menjadi lebih menarik dan lebih indah. Hal ini sesuai dengan pendapat Pamadhi (2011: 2.59) yang menyatakan bahwa kita dapat menangkap keindahan pada susunan warna. Warna dalam karya berupa kombinasi warna yang ada, begitu juga siswa yang memberikan pewarnaan pada bidang dasarannya atau pada latarnya. Selain itu warna bermanfaat bagi siswa karena memiliki manfaat lain seperti yang disampaikan Akmal (2006: 25) bahwa "warna-warna mampu merangsang gerak motorik serta perkembangan otak anak".

Warna yang terdapat dalam karya seni menggambar dekoratif pada caping adalah warna primer, sekunder dan tersier sesuai dengan warna yang dipilih siswa. Namun secara keseluruhan, warna primer adalah warna yang paling banyak digunakan. Hal ini sesuai dengan pendapat Akmal (2006: 24) bahwa "warna primer merupakan warna yang paling mudah dikenali. Biasanya anak-anak mulai belajar dengan mengenali warna-warna ini terlebih dahulu. Tak heran bila gabungan tiga warna primer ini paling banyak digunakan”.

Setelah unsur seni rupa dibahas dilanjutkan dengan prinsip seni rupa. Prinsip yang pertama adalah prinsip kesatuan. Prinsip kesatuan dalam seni rupa adalah terbentuknya berbagai unsur yang saling menunjang satu sama lain dalam membentuk komposisi yang baik dan serasi. Prinsip kesatuan pada karya sudah terlihat. Unsur-unsur seni rupa yang terdapat pada karya yang telah dibuat seperti garis, bidang, warna dan gelap terang, posisi gambar terlihat saling menunjang. Prinsip kesatuan ini terdapat pada karya-karya selain kelompok empat karena karya pada kelompok ini motif yang dibuat kurang kontras. Hal ini sesuai dengan pendapat Kamaril (2006: 3.22) bahwa "untuk menyusun suatu kesatuan setiap unsur tidak harus sama dan seragam, tetapi unsur dapat berbeda dan bervariasi, tetapi diupayakan menjadi susunan yang memiliki kesatuan”.

Prinsip keseimbangan adalah upaya untuk menyeimbangkan antara kiri kanan, atau atas bawah sehingga memiliki kesamaan bobot. Prinsip ini harus diperhatikan dalam pembuatan karya seni menggambar dekoratif, pinsip ini terlihat dari penyeimbangan gambar motif dan keseimbangan penggunaan warna. Keenam hasil karya yang telah dibuat juga mulai memperlihatkan prinsip keseimbangan meskipun ada beberapa karya yang masih kurang. Sesuai dengan pendapat Kamaril (2006: 3.23) bahwa keseimbangan memiliki kesamaan bobot dari kesemua unsur dasar karya seni rupa.

Prinsip Irama dalam seni rupa dapat tercipta atas dasar perbedaan dan peletakan. Secara ringkas dapat dikatakan bahwa irama dalam pemahaman seni rupa merupakan susunan atau perulangan dari unsur-unsur rupa yang diatur, berupa susunan garis, bentuk maupun susunan warna. Dengan demikian irama dalam karya seni rupa terjadi dari pengaturan unsur-unsur rupa baik garis, bidang, warna dan gelap terang secara berulang. Semua karya yang dihasilkan setiap kelompok menggunakan irama repititif yaitu pengulangan motif dengan ukuran yang sama. Namun, ada beberapa kelompok yang membentuk irama progresif yaitu pengulangan motif dengan pola atau ukuran yang berbeda. Hal ini sesuai dengan 
Kamaril (2006: 2.24) bahwa irama repetitif adalah perulangan dengan ukuran yang sama dan progresif adalah perulangan dengan ukuran yang berbeda.

Prinsip penekanan pada objek tertentu dalam seni rupa merupakan bentuk penekanan. Fokus utama objek yang terdiri atas beberapa bagian, atau di antara menjadi lebih menonjol. Tujuan penekanan ini untuk memberi pusat perhatian atas objek yang ditampilkan dalam sebuah karya seni rupa. Pada hasil karya yang telah dibuat, prinsip penekanan ada pada penekanan warna dan motif yang menunjukkan ekspresi dari karya yang telah dibuat. Penekanan yang digunakan siswa dalam karya tidak hanya berupa penekan pada motif, namun juga penekanan pada segi warna. Penekanan motif terdapat pada karya kelompok 1, 2, 3, 5 dan 6. Sedangkan karya kelompok 4 menekankan pada segi pewarnaan. Penekanan menurut Kamaril (2006:3.27) adalah prinsip penekanan yang disebut juga dengan prinsip dominasi dimana dalam karya seni rupa dapat dicapai memalaui berbagai alternatif.

Prinsip keserasian atau keselarasan merupakan prinsip yang digunakan untuk menyatukan beberapa unsur seni rupa walaupun berasal dari berbagai bentuk yang berbeda. Keserasian dalam seni rupa dapat meliputi masalah warna atau komposisi lain yang membentuk sebuah karya seni rupa. Karya seni menggambar dekoratif pada caping yang dibuat oleh siswa ini telah memiliki prinsip keselarasan dalam seni rupa. Karya yang telah dibuat memiliki keselarasan baik motif yang dipilih dan warna dengan motif karya, karya yang dihasilkan telah memenuhi prinsip keselarasan atau keserasian. Keserasian menurut Kamaril (2006: 3.27) adalah prinsip yang digunakan untuk menyatukan unsur-unsur rupa walaupun berasal dari berbagai bentuk yang berbeda.

\section{Simpulan}

Proses pembuatan karya seni mengambar dekoratif pada caping yang dibuat oleh siswa kelas III A SD Negeri 07 Kota Bengkulu. Yang dilakukan oleh keenam kelompok yang dimulai dari persiapan dan langkah kerja. Persiapan dimulai dengan mempersiapkan alat yaitu pensil, spidol dan kuas serta bahan yaitu caping dan pewarna. Dilanjutkan dengan langkah pembuatan yang dimulai dari memberi cat dasar pada caping, lalu mendesain motif geometris, hewan, tumbuhan dan manusia sesuai dengan kesepakatan bersama serta yang terakhir pewarnaan. Keenam kelompok telah melakukan setiap persiapan dan langkah pembuatan karya seni menggambar dekoratif pada caping. Namun, masih terdapat sedikit kendala disetiap kelompoknya seperti dalam proses mendesain motif dan mewarnai pada permukan caping karena permukaan caping yang tidak rata. Selain itu, anak-anak belum bervariasi dalam menggunakan warna.

Hasil karya yang dibuat oleh siswa kelas III A SD Negeri 07 Kota Bengkulu terlihat unsur-unsur dan prinsip-prinsip seni rupa. Unsur-unsur yang terlihat dalam keenam karya tersebut adalah garis, bidang, dan warna. Prinsip-prinsip yang terlihat dalam setiap karya meliputi kesatuan, keseimbangan, irama, penekanan, dan keserasian. Dari hasil karya seni menggambar dekoratif pada caping yang dibuat siswa telah menunjukkan bahwa siswa telah memiliki daya kreativitas yang baik. Siswa telah mampu menuangkan ide ke dalam suatu karya yang belum pernah mereka buat sebelumnya.

\section{Saran}

Berdasarkan hasil penelitian yang telah dilakukan, maka peneliti memberikan saran sebagai berikut. 
1. Dalam proses mendesain motif dengan menggunakan pensil disarankan untuk tidak menggunakan pensil yang ujungnya telalu runcing. Ujung pensil yang digunakan sedikit tumpul supaya dalam mendesain akan lebih jelas motif yang dibuat.

2. Pada saat proses pewarnaan disarankan untuk kuas yang diberikan lebih dari 3 kuas supaya proses pewarnaanya tidak memakan waktu yang lama.

3. Bagi peneliti selanjutnya diharapkan untuk dapat membuat karya seni menggambar dekoratif dengan menggunakan benda-benda yang lain yang merupakan benda tiga dimensi yang permukaannya datar atau polos.

\section{Referensi}

Akmal, I. 2006. Menata Rumah Dengan Warna. Jakarta: PT Gramedia Pustaka Utama.

Aminuddin. 2009. Apresiasi dan Ekspresi Seni Rupa. Bandung: Puri Pustaka.

Bassano, \& Mary, dkk, (2015), Terapi musik \& warna, cara Dasyat Hidup Lebih Sehat dan Bahagia. Yogjakarta: Araska.

Irawan, B., \& Tamara, P. 2013. Dasar-Dasar Desain. Jakarta: Griya Kreasi.

Kamaril, C. 2006. Pendidikan Seni Rupa/Kerajinan Tangan. Jakarta: Universita Terbuka.

Muliawan. 2016. Mengembangkan Imajinasi dan Kreatifitas Anak, Yogjakarta: Gava Media.

Pamadhi, H., dkk. 2011. Pendidikan Seni di SD. Jakarta: Universitas Terbuka.

Pekerti, W. 2007. Pendidikan Seni Musik. Tari/Drama. Jakarta: Universitas Terbuka.

Sugiyono. 2010. Metode Penelitian Pendidikan Kuantitatif Kualitatif dan R\&D. Bandung: Alfabeta.

Sumanto. 2011. Pendidikan Seni Rupa di Sekolah Dasar. Malang: FKIP Universitas Negeri Malang.

Suroso. 2010. Smart Brain, Metode Menghafal Cepat dan Meningkatkan Ketajaman Memori. Surabaya: SIC.

Susanto. 2014. Teori Belajar dan Pembelajaran. Jakarta: Kencana. 